\title{
Carita Pantun Storytelling
}

Baduy pantun stories are part of the larger Sundanese oral tradition of pantun storytelling in west Java. The stories recount the deeds of the nobility of such old Sundanese kingdoms as Pajajaran and Galuh. This chapter discusses the Baduy version of pantun storytelling. ${ }^{1}$ It summarizes earlier major publications and analyses some performance aspects of two Baduy pantun stories that I recorded. Although I do not concentrate on the text, I will discuss a few cultural issues arising from the texts. Baduy oral literature also includes children's and women's songs, as well as fables and myths of origin (dongéng) which do not involve music. These will not be discussed here. For recorded Baduy susualan song texts for entertainment I refer to Appendix 4 and Chapter 7 .

\subsection{Baduy Oral Literature in the Larger Sundanese Context}

Like other groups elsewhere in the Sundanese area, the Baduy know pantun stories and still perform them. In fact, although the Baduy still regularly recite pantun, in the larger towns of West Java the recitation of pantun seems to have disappeared almost entirely. Nevertheless, the pantun stories are still known and part of this heritage lives on in other genres, among them wawacan singing and Tembang Sunda Cianjuran (Van Zanten 1989; 1993), and in film and theatre (Eringa 1949: 16-8; Kartini and others 1984:1).

In west Java a $(\text { carita })^{2}$ pantun is an epic narrative sung by a male singer who generally accompanies himself on a zither (kacapi), but sometimes on a twostring bowed lute (tarawangsa). Eringa (1949:3) stated that the Baduy are only allowed to use the kacapi for accompaniment of the recitation. This is confirmed by my findings: I have never heard that the Baduy can use a tarawangsa or their similar rendo for this accompaniment. On occasions the Baduy can

1 It is based on Van Zanten 2016a, however I have removed a few sections and added new information obtained during fieldwork in July 2016 in and around Kanékés.

2 Carita means 'story' in Sundanese. In the Baduy pantun recitations, the word lalakon is often used instead of carita: Lalakon Paksi Keuling, the Story of Paksi Keuling. Baduy and Sundanese carita pantun should not be confused with the Malay pantun, which is a specific type of short poem which occurs in many traditions of the Malay world. In Sundanese this form is called sisindiran or susualan (Van Zanten 1989: 18-21, 1993: 144). See also Chapter 7 . 
also perform a pantun story without any instrumental accompaniment as did the storytellers Sawari in 2003, Anirah in 2014 (see Section 6.4 below), and the pantun performers I heard during the circumcision rituals in 2016 (see Sections 4.4 and 4.5 ).

A pantun is performed in a recitational chant, occasionally alternated with melodically more elaborate songs, interspersed in the long recitatives. The rate of recitation varies from normal speech tempo to either much faster or much slower. In Van Zanten (1993) I have discussed the performance aspects of some 'melodically more elaborate songs' in pantun recitation in Bandung and the transformations undergone by these songs when they were adopted into the tembang Sunda Cianjuran repertoire in the nineteenth century. I have also discussed the text of the beginning (rajah or rajah pamunah) of a recorded pantun recitation ${ }^{3}$ by Enjum from Ujungberung, Bandung, in 1981, and have shown that it was remarkably similar to the text published in Eringa (1949: 138) and Pleyte (1910: 135-136). ${ }^{4}$ Interestingly, the rajah text of the recordings of pantun stories since the $1970 \mathrm{Os}^{5}$ are at least four to five times longer than the rajah texts given in Pleyte and Eringa (Van Zanten 1993: 145-146). Below I shall show that the Baduy rajah texts are different to this Preanger text.

The Sundanese - and also Baduy - pantun contain myths and legends about the nobility of such ancient Sundanese kingdoms as Pajajaran and Galuh. Most stories deal with the hero's period of initiation before marriage. The stories Mundinglaya di Kusumah and Lutung Kasarung are good examples of this type of tale. It is possible that the Sulanjana story might be a myth about the origin of rice (Pleyte 1913, Vierde Stuk: 1-17 (in Sundanese) and ${ }^{18-35}$ (in Dutch)). Rice as a gift from the 'heavenly mother' Sunan Ambu is also an important theme in the pantun Lutung Kasarung (Eringa 1949; in Sundanese with translation into Dutch). Other Sundanese pantun stories are non-indigenous Islamic tales and historical tales (babad) from Cirebon. Weintraub (1990: 21), who investigated the musical aspects of pantun performances by the storyteller Enjum from Ujungberung, Bandung, lists stories

3 This sung beginning of a pantun story (rajah) is an invocation in which the singer invokes the protection and blessing of the gods, asking pardon for any possible mistakes he might make in his telling of the story. The Baduy rajah will be discussed in more detail in Section 6.5 below.

4 The text of Pleyte (1910) originated in Cirebon in the Preanger area: see the table with Pleyte's publications of pantun texts in Van Zanten (2016a: 413-414).

5 See, for instance, the recordings made by Ajip Rosidi, Andrew Weintraub and myself, listed in Appendix 1 in Van Zanten (2016a: 428-429). 
about the gods, like Batara Kala, which was used by Enjum for the purification of a person, as a fourth category.

This chapter raises the issue of the relationship between the content and context of the Baduy pantun to the wider category of Sundanese pantun. This is still rather blurred and should be investigated in more depth. So far, Eringa (1949) has given the most thorough discussion of the text and socio-cultural background of a pantun story and in his work he frequently refers to the Baduy. Kartini and others (1984) have presented the synopses of thirty-five and Sumardjo (2013) has presented the synopses of eighteen of the wider category of Sundanese pantun stories in Indonesian. Weintraub (1990:167-197) has supplied synopses of five stories, recorded in the Bandung area, in English. Nevertheless, the most important sources for the full text of a pantun story are still the publications produced by C. M. Pleyte between 1907 and 1916, and those of Rosidi in the 1970s. The text analyses in Kartini and others (1984) and Sumardjo (2013) are still heavily based on these manuscripts and less on original fieldwork data collected by the authors. Sumardjo (2013:3) wrote that he had never attended a pantun performance and had 'only read several pantun stories and pantun transcriptions'.

Sundanese pantun stories are recited at such ceremonies as circumcisions, weddings or harvest celebrations. They are also narrated on the occasion of the purification (ruatan) of a person, or that of a house or some other object (ruat tumbal, see Weintraub, 1990: 14; see also Pleyte, 1910: xx-xxii; Eringa, 1949: 14-19). This statement is equally valid for the Baduy pantun and below I shall mention the recitation of a pantun story for the inauguration of a new hamlet (nukuh lembur) in the Baduy village Kanékés in 2014. See also Sections 4.4 and 4.5 above for pantun stories recited during circumcision rituals. It is said that on such occasions, the story may be recited from about eight o'clock in the evening and can last until five o'clock in the morning. However, I have not heard a Baduy recitation lasting for more than 3-4 hours. The pantun stories are said to come 'from the abode of the gods' (Eringa 1949: 38-9; Van Zanten 1993: 156) and, before the recitation begins, incense will be burnt, an offering (sasajén) will be placed before the player and in the rajah, mentioned above, he will ask permission from the gods and the ancestors to tell the sacred story.

The Baduy also have stories (dongéng) that are less connected to their rituals than the pantun stories are. Furthermore, Baduy oral literature also includes children's and women's songs, formal speech, magical formulae (mantra, jampé) and the songs used purely for entertainment, like the above-mentioned sisindiran or susualan (see also Beberapa cerita rakyat Baduy 1975; Hamidimadja 1998). Pleyte (1912) presented the full text of the pantun story Paksi Keuling 
and three Baduy fables in the original Sundanese with a Dutch translation plus comments: Oa jeung Aul (Oa and Aul), ${ }^{6}$ Ratu Manuk (The king of the Birds) ${ }^{7}$ and Séro jeung Keuyeup (The Otter and the Tortoise).

In this publication Pleyte (1912: 254-261) also included several short sisindiran poems, and the transcribed texts of two myths of origin: Mula Nagara Baduy (The Origin of the Baduy Community) and Déwa Kaladri (The God Kaladri: the big-bellied son of the highest god, Batara Tunggal). The story about the origin of the Baduy community is particularly interesting because it mentions that the Baduy are descendants of the king of Pajajaran and his followers: at the time of the Islamization of Pajajaran the king, who did not want to become Muslim, left Pajajaran with his followers and founded the hamlets Cibéo, Cikeusik and Cikartawana (Pleyte 1912: 261-266). Currently the Baduy strongly deny that they are descendants of the Pajajaran king and his followers, who supposedly fled to Kanékés when the kingdom fell to the sultan of Banten in 1579. See for a recent overview of the publications on Baduy history Wessing and Barendregt (2005) and also the remarks by Danasasmita and Djatisunda (1986: 90-91) discussed on the first two pages of Chapter 3 above.

Geise (1952: 109-116) has also presented a few Baduy stories about the origin and organization of the Baduy society and its relationship with the outside world, particularly mentioning the very important relationship between Baduy society and the rulers of Banten in Sérang: in a classificatory sense the Baduy are the elder brothers of the rulers in the north, as related in the story of Budak Buncireung (Geise 1952: 116; see also Garna 1988: 48, 405-408). This relationship is reconfirmed each year in April-June when a Baduy delegation sets out on a three-day trip to offer some agricultural produce and craft products to the regent (bupati) of Rangkasbitung and the governor of Banten province in Sérang during the séba ceremony. In 1905 the séba delegation consisted of seven Baduy (Pleyte 19o9: 494), but about a century later its size increased from about 500-6oo Baduy men in 2003 to almost 2,000 in 2015. The Banten government has seized upon the opportunity to promote this ceremony, which fits in very well with its policy of making the Baduy an object of cultural tourism (obyek wisata budaya); see further Section 2.4 and Van Zanten (2004: 145-147).

Pantun stories are already mentioned in Old Sundanese manuscripts. The manuscript Sanghyang Siksakanda ng Karesian, dating from 1518, mentions four pantun titles: 'If you want to know about the pantun [stories]

$6 \mathrm{Oa}$ is a kind of grey monkey (gibbon) and aul is a fablulous animal which is supposed to resemble a monkey. It continuously spits around itself (Eringa 1984).

7 Pleyte (1912: 237, 241-243) remarked that this story about the administrative structure of the world of the birds is a reflection of the major organizational principles of Baduy society. 
Langgalarang, Banyakcatra, Siliwangi [and] Haturwangi, ask the pantun singer'8 (Atja and Danasasmita 1981: 14, 40). These four titles are not mentioned in the list of thirty-nine titles supplied by Eringa (1949: 9-13) - in addition to the Lutung Kasarung story which is presented in his book - nor in the list of twenty-six titles mentioned by Rosidi (1973: 110-1), seventeen of which were not included in Eringa's list. Altogether this adds up to almost sixty different stories. On the Internet, I have seen one list which contains 127 titles of pantun stories, but for the moment it will be safer to restrict the number of known at present as pantun stories to about sixty.

Basing himself on De Haan (1910-12, Vol.2: 287), Eringa (1949: 7) concludes that the earliest printed remark about the existence of pantun stories was made in a report by Abraham van Riebeeck (later Governor-General of the Dutch Indies) in 1704: 'In the evening before and during dinner we had Javanese music about Ratu Pajajaran [the king of Pajajaran]. ...' ${ }^{9}$ Spanoghe (1838: 303) mentions that the (Inner) Baduy are 'only allowed to recite pantun stories (pantong), singing a song in which a story of long ago is told'.10

In their book on three Old Sundanese poems, Noorduyn and Teeuw (2006:1011, 278-281) briefly discuss the relationship between the pantun tradition and the written Old Sundanese poetry. As do the ancient written texts, the pantun singer favours an octosyllabic verse line and 'Both types of texts bear a formulaic character; especially the pantun sung by Baduy bards contain a number of formulas or formulaic expressions, identical or similar to those found in Old Sundanese poems ...' They also point out that there is a close correspondence between the introductory part of a text in Old Sundanese manuscripts and the sung introduction (rajah) of the pantun, the invocation in which the singer asks for the protection and blessing of the gods in the event of any possible mistakes he might make when telling the story. Section 6.5 below will briefly discuss a few issues mentioned in the recited texts of the two Baduy rajah which I recorded.

\subsection{Baduy Pantun Stories}

The annotated list of pantun titles compiled by Eringa (1949: 9-13) does include pantun stories which had been stated earlier by Meijer (Jacobs and

$8 \quad$ Hayang nyaho di pantun mah: Langgalarang, Banyakcatra, Siliwangi, Haturwangi; prěpantun tanya.

9 's Avonts voor en onder 't eeten hadden wij 't Javaens musijq van Ratoe Padjadjaran ...

$10 \quad$ [The (Inner) Baduy] '... mogen niet anders zingen dan Pantongs (een zang waarin eene of andere geschiedenis van lang verledene tijden verhaald wordt).' 
Meijer 1891: 135) to belong to the Baduy repertoire. Meijer listed ten Baduy pantun, their 'entire repertoire', which were still being performed and he had heard from Baduy performers whose the names are given:

Jasini performed:

Yasti performed:

Sarsimin performed:
Bima Wayang, Gajah Lumantang, Kuda Gandar; Kuda Wangi, Langga Sari, Radén Tegal, Ranggah Séna; Paksi Ke(u)ling, Panambang Sari; Kidang Panandri.

A summary of each of these ten stories, considered to be specific to the Baduy, is attached by Jacobs and Meijer (1891: 153-166). Meijer also gave five titles of pantun which were known to the Baduy bards but could no longer be performed: Badak Singa, Ciung Wanara, Kidang Pananjung, Lutung Kasarung and Matang Jaya. Meijer stated that only a few Baduy, who belonged to different families, could recite pantun stories (Jacobs and Meijer 1891: 135). He also remarked that, beyond the Baduy area, there were no pantun performers in Banten, the westernmost region of Java. Other pantun performers could only be found to the east of Kanékés in the Preanger area, the mountainous area of west Java situated roughly between Bogor and Ciamis.

Jacobs and Meijer (1891: 143) pointed out that most male heroes of the pantun stories bear an honorific title which is the name of an animal: Badak (rhinoceros), Ciung (béo, a kind of blue-black starling which can be taught to speak), Gagak (crow), Gajah (elephant), Galudra (a mythical bird; Indonesian: garuda), Kidang (small deer), Kuda (horse), Lutung (black monkey), Munding (buffalo), Naga (mythical snake), Paksi (bird), Ranggah (deer) or Singa (lion). They added that the name of heroines is often preceded by Lénggang ('brightly shining').

At this point, I would like to make a few additional remarks about these honorific titles. Cloud (méga) in combination with a name is frequently found in pantun stories, for instance, the story of Paksi Keuling. This story also tells of a hero called Méga Kumendung, that is, 'Cloud which protects with its shade.'11

11 Mendung means 'dark clouds', 'clouded', 'overcast', used for the sky, and also metaphorically for a person's face. It is in this sense it occurs in the first line of the pantun text given by Eringa (1949: 138): Bul kukus mendung ka manggung, 'I burn incense, in dark clouds rising' (see also Section 6.5 below). However, mendung/ngabendung can also mean 'to screen off shade', 'overshadow', and in this respect Coolsma (1884) mentions as an example 'an eagle gliding in the air' which 'obscures the sun'. Bearing this in mind, the name Méga Kumendung might be translated as 'the cloud which protects [us from the sun] by its shade', possibly referring to a king/hero who mediates between the gods and the king's 
'Cloud' also occurs in women's names, for instance, Nyi Méga Langlayang Buuk Lenggang Larang Kancana. The names of plants, like saninten (edible chestnut) in Saninten Kancana, rinu (kind of pepper plant, piper cubeba) in Rinu Wayang, Rinu Rarang and Rinu Kasih, kembang (flower) in Kembang Panarikan and pucuksari (opening flower) in Pucuksari Ratna Wentang are sometimes used in women's names. Also associated with the names of women are objects specific to the female world, for instance, sumur (well) in Sumur Bandung (see Kartini and others $1984: 28,48,53,66,68,80,109)$. This list is certainly not exhaustive, but to delve any deeper here is beyond the scope of this chapter.

Although nowadays most Baduy stories are also not unfamiliar in other parts of west Java, a comprehensive discussion of the differences in content and performance still remains to be done. Kartini and others (1984) supplied the structure and a summary of thirty-five Sundanese pantun stories taken from the literature. As some of these are variant versions of the same story, in fact they have actually supplied twenty-seven different in total. Although Kartini and others mentioned that fourteen in this set of thirty-five stories are categorized as 'from Banten' (Kartini and others 1984: 10), they did not give a precise indication of what they consider a 'Baduy pantun' to be. ${ }^{12}$ Pleyte has stated that Badak Pamalang may have been a Baduy story (Pleyte 1916: 537, Eringa 1949: 9) and he also mentioned that he transcribed the story Paksi Keuling directly from a performance given by the Baduy storyteller Japar/Dascin (Pleyte 1912; see Section 6.3 below).

Eringa (1949: 8-9) was fairly critical of Meijer's summaries of the ten pantun stories in Jacobs and Meijer (1891: 153-166): he considered these too short and also postulated that much information had just not been obtained, probably because the Baduy did not want to part with this. Eringa pointed out that the long pantun stories given by Pleyte about twenty years later seem to confirm the suspicion that the short versions recorded by Meijer were incorrect renderings. He also cast doubts on Meijer's remarks that the stories Lutung Kasarung and Ciung Wanara were no longer performed: as these two stories belong to the most sacred of the repertoire, it was far more likely that the Baduy simply did not want to disclose their contents to an outsider. My audio recording of the Lutung Kasarung story told by the Baduy storyteller Sajin in January 1977 (see below) corroborates Eringa's criticism. After recording the pantun story,

subjects/the hero's followers. I am grateful to Clara Brakel who referred me to Coolsma's dictionary for kumendung, although I remain entirely responsible for the interpretation of Coolsma presented here.

12 In the 1980 report on which this publication is based, they used the category 'Banten/ Baduy' on page 24 . 
I was told by the Outer Baduy Talsim, who accompanied the Outer Baduy storyteller Sajin, that pantun stories should be considered to be part of 'religion' (agama) and not 'art' (kesenian) (Van Zanten 1995: 530), adding that I had obtained the sanction of the Baduy to make this recording.

During my fieldwork among the Baduy, usually I only managed to obtain limited and conflicting information about which Baduy pantun stories are still performed. However, on 2 April 2003 I did gather some interesting information from the former Baduy musician Usman and on 5 April 2003 from the Inner Baduy Karamaén..$^{13}$ The information from Usman and Karamaén proved to be consistent, as both of them told me that the three most important stories were Raja Lumantang, Langga Sari and Lutung Kasarung. The other stories are used less often. The Langga Sari story, which takes about six hours to perform, is used for 'curing the rice' (pengobatan padi), that is, to protect it from diseases and insects, ${ }^{14}$ and when moving into a new house. The Raja Lumantang story, which takes two nights to perform, is used for such celebrations as marriages and circumcisions. Karamaén stated that the Lutung Kasarung story, which takes three to four hours to perform, is an 'Outer Baduy story', used for marriages, but that it is not performed in the Inner Baduy area. ${ }^{15}$ Usman said that the Lutung Kasarung story was suitable for 'everyday' (sehari-hari) happenings, which means that it could be used for many purposes.

Usman added that a pantun recitation might last for just a few hours. For instance, the 'curing' of the rice in the Inner Baduy area takes three to four hours pantun performance. However, a recitation can also take the whole night (eight-nine hours) with just a short break of half-an-hour for a meal. Moreover, if the story is too long to be recited in one night, it will be told in parts over several nights. This breaking up into parts also occurs in the performance of longer pantun (and wawacan and wayang) stories told in the Priangan: the entire story can take two or three nights to perform.

On 2 April 2003, the pantun singer Sawari told me that Raja Lumantang was the longest story and took him three nights to perform. The shortest story was

13 Usman is of Inner Baduy descent. He has been living in the resettlement hamlet Cipangembar since 1978 and therefore no longer belonging to the Baduy community. Usman is very knowledgeable about Baduy music and I interviewed him several times between 1992 and 2014. Karamaén lives in the Inner Baduy hamlet Cibéo. He is also very knowledgeable about music. See further Appendix 3.

14 Djatisunda (1995: 9) mentions that the stories from the pantun Linggasari [Langga Sari?] are often used as medicine for the rice.

15 This contradicts what Danasasmita and Djatisunda (1986: 83) wrote, namely that this story Lutung Kasarung, especially in the Inner Baduy area, belongs to the sacred ones (tergolong sacral), because it tells about how to look after the rice. 
Paksi Keuling and took three hours to perform. Sawari considered the Lutung Kasarung story was too long for one night. At the inauguration (nukuh lembur) of the new hamlet Campaka, Kanékés, which I attended in 2014, a pantun recitation of the story of Langga Sari, was told for two-and-a-half hours on the night of Wednesday 4 June- early morning Thursday 5 June, 2014 (see Section 6.4 below).

Pantun singer Anirah said that the pantun story Buyut Orényéng was used for asking protection when going for a hunt. It should be performed at least once a year and at a location where two rivers meet (A2016-1: 20). ${ }^{16}$ According to a neighbour of Anirah in Kaduketer 2 a section of about five minutes from the Buyut Orényéng story would be performed during the circumcision ritual, when the boys (and girls?) are ceremonially bathed in the river, just before they will be circumcised in the morning of the third day (bubaran, A2016-1: 38; see also Sections 4.4 and 4.5 about circumcisions in 2016). This was later partially denied by Anirah: it is a section of the pantun story Langga Sari that will then be performed. ${ }^{17}$ According to Anirah the Langga Sari story consists of two parts: Langga Sari Matang Wangi that is mostly used for the curing of rice, and Langga Sari Matang Jaya that is used for weddings and circumcisions (A20161: 43-44). Hence the Matang Jaya story mentioned by Jacobs and Meijer (see above) most probably is a section of the Langga Sari story.

When asked, Ayah Anirah also commented on the other pantun stories mentioned by Jacobs and Meijer. According to Anirah the Gajah Lumantang was probably Raja Lumantang, a story that he knew about, but that he could not perform himself. This story tells about life after death, what human beings can expect after they die (compare end of Section 4.6). In contrast to what Karamaén and Usman told me, Anirah said that this story was not often performed. When performing the storyteller has to sit a little lower than the veranda on which the people sit, who attend his performance. Anirah added that currently such houses with a special place for the performer are rare (A20161: 42). The story Kidang Panandri (Jaya) mentioned by Jacobs and Meijer was the same as Raja Lumantang, and mainly sung with the Inner Baduy. The story Kuda Gandar was part of the story Langga Sari. Anirah knew Kuda Wangi as the normal story (dongéng) Sang Ratu, but not as a pantun story that is recited.

Ayah Anirah's made an intriguing remark about the story Radén Tegal, mentioned by Jacobs and Meijer. He knew the title, but could not perform this story

16 In July 2016 both Anirah and Karamaén said that 'orényéng' means 'bad, not good, mad' (half human - half animal?; A2016-1: 40, 47).

17 This may be the episode of Béngkong séda sakti, 'the sacred person who carries out the circumcision', taken from the Langga Sari story, mentioned in Section 4.4. 
himself. This story was used in the kawalu fasting months or when a woman was over time with her pregnancy. Anirah told that in Cikeusik there may still be storytellers who can perform this story, but it could also be that this knowledge has disappeared with the older teachers (A2016-1: 43-44).

\subsection{Pantun Texts and Audio-Visual Recordings since 1905}

While he was employed in Batavia (Jakarta) in the 19oos and 1910s, Cornelis Marinus Pleyte (1863-1917) took the opportunity to study the oral literature of the Sundanese, including the Baduy. Without any doubt Pleyte is one of the main sources for pantun recitations in the past (see also Eringa 1949: 79). Interestingly Pleyte also paid attention to the music played when a pantun was being performed and also supplied some information about his methodology and the social setting of the performance in his publications. He heard Baduy pantun performers on a number of occasions. For instance, in Pleyte (1907: 6) he writes about the performances of Sundanese pantun which he attended in the Banten region, including some by Baduy performers: 'Excellent was of course the elder (kokolot) from Cibéo, one of the Inner Baduy hamlets. We were able to listen to his [pantun] singing in Sérang for four nights; he sang the genuine, unadulterated ancient story'.

Pleyte's main Baduy informant for the oral literature of the Baduy was Japar, formerly called Dascin (see photograph of him in Pleyte 1912: 214), a former Inner Baduy and son of a high-ranking official (girang seurat) of Cikeusik, who became Muslim and lived at the Regent's court in Sérang. On the basis of his personal observations and his discussions with Japar, Pleyte (1912: 217) reported that: 'Baduy are loath to allow strangers to study their customs (adat)'. After he had perceived Japar's reluctance to talk about the Baduy way of life, Pleyte proceeded more circumspectly. He began by asking Japar to tell about his travels in west Java, beyond the village of Kanékés. This request presented no problem and gradually the road was paved for the transcribing of some Baduy stories, including the pantun story Paksi Keuling as recited by Japar (Pleyte 1912: 215-221).

As far as I know, at that time (about 1905-1915) Pleyte did not use any audio recordings for his transcriptions of pantun texts. Presumably in the description of his methods (Pleyte 1912: 217-221, 291) he is referring to his collaboration with Japar between 11 June and 10 September $1911 .{ }^{18}$ Japar recounted his travels

18 On the basis of Pleyte's letter of 10 September 1911 to Snouck Hurgronje, kept at the Leiden University Libraries Or.8952 A: 831, in which he wrote about his fieldwork on Baduy pantun. 
through west Java, told stories and also 'plucked his kacapi and sang about the vanished greatness of his people tirelessly night after night' (p. 218). As he talked and recited, Pleyte 'kept writing down' what Japar said (p. 219). Although not explicitly stated, I assume that afterwards Pleyte did check his notes with the performer Japar, as he did remain in contact with him. ${ }^{19}$ Most probably the music transcription of the beginning of the pantun story Paksi Keuling by 'a very gifted female pianist' whose name is not given 'at her explicit request' was accomplished in a similar manner (see transcription of the music 'Lagoe pantoen - Pantoen-melodie' on the four unnumbered pages in Pleyte 1912, after p.425). In the case of the other pantun texts, Pleyte relied either on performances which he had attended or on existing manuscripts, such as those from Tegal (Pleyte 1916). Only the story mentioned in Pleyte (1912) was based on the recitation of a (former) Baduy; none of the other stories had been recited either by a Baduy or someone from Baduy descent. See for a list of the published texts of pantun stories by Pleyte Table 1 in Van Zanten 2016a: 413-414)

As said, the only complete story text performed by a (former) Baduy was Paksi Keuling published in 1912. Pleyte (1916: 56) remarked that, only in the two pantun manuscripts (Rangga Sawung Galing and Deugdeugpati Jayaperang) from Tegal, situated about $70 \mathrm{~km}$ east-south-east of Cirebon, is there any indication about where the performer commences the melodically more elaborate singing. In these two pantun texts from Tegal, Pleyte gave a few titles of the melodies. These given melodies are: Dayungan ('Rowing', p.65), Mojang Dangdan ('The girl dresses herself before departure', p. 69, 474), Ponggawa Nyurung ('the officials push', p. 84, 487), Silir (a kind of dance, p. 93, 482, and 489) and Tonggérét Pakuan ('The cicada of Pakuan', p. 472). Discussing the Priangan tradition, Sukanda (1978: 9-10) described these 'songs', which alternate with the recitation of the story, as lagu panganteb pantun, that is, 'songs to intensify the (beauty of the) pantun'. In the first half of the nineteenth century, they were one of the sources for songs in the Tembang Sunda Cianjuran repertoire (Van Zanten 1989: 21-23, 1993: 148).

I was particularly interested in the letters between Pleyte and Snouck Hurgronje, because of the wax cylinder recording of the commencement (rajah) of a pantun recitation made by Snouck Hurgronje around 1905 (see below). Did Pleyte help to find the performer for this recording, not to mention the other

19 In a letter to Snouck Hurgronje dated 3o September 1912 (Leiden University Libraries, Or. $895^{2}$ A: 832 , page 8), Pleyte wrote that he had just received a letter in which Japar had written about another Baduy, who had left Kanékés and had just been awarded a diploma for passing the 'second class' of the School for Indigenous People (Inlandsche School) in Rangkasbitung. 
Sundanese recordings made by Snouck Hurgronje at that time (see Van Zanten accepted for publication)? Did Snouck Hurgronje and Pleyte discuss the possible use of the phonograph for recording some more pantun parts - on average about three minutes long - on wax cylinders? ${ }^{20}$ Unfortunately, the letters from Pleyte to Snouck Hurgronje in the period between 27 April 1905 to 13 January $1915^{21}$ say nothing whatsoever about audio recordings. No letters from Snouck Hurgronje to Pleyte have been preserved in this collection.

In the 1980 os I recorded four pantun stories (one story recorded twice) as recited by Enjum from Ujungberung, Bandung, who followed the Priangan tradition (Van Zanten 1993). I only recorded (parts of) two Baduy pantun stories: Lutung Kasarung in 1977 and Paksi Keuling in 2003. These recordings were both made outside the Baduy village Kanékés. By 1992 several pantun bards were in fact willing to make an audio recording, but only outside Kanékés. I was then told that, within Baduy territory, the recitation of pantun stories can only take place within a ritual context (Van Zanten 1995: 521). Although pantun stories were not my main concern, I did continue to ask permission to record a pantun in ritual context in Kanékés in both 2003 and 2013, but this was never granted. Only in 2014 and 2016 was I invited to attend pantun performances in ritual context in Kanékés, but I had to remain outside the house in which it took place and was not allowed to make any recordings (see Section 6.4 below and Sections 4.4 and 4.5 above).

In this section, I would like to discuss the audio(visual) recordings of pantun in west Java in general and put the very limited number of Baduy recordings available in that perspective. In 1993 I wrote, 'As far as I know there are no audio recordings of pantun before the 1970s. Dutch scholars like Pleyte and Meijer wrote down only the texts of pantun around 19oo'. (Van Zanten 1993: 148). I was wrong. Probably the earliest audio recording of the beginning of a pantun story was made in Jakarta (?) by Snouck Hurgronje on a wax cylinder around 1905. On Cylinder I-10, kept at the Leiden University Libraries, is written 'Djampe njawer. Lagoe Galoeh' (Jampé nyawér. Lagu Galuh). It is almost certain that the male performer is singing the introductory song to a pantun story (rajah). The text from this (digitalized) old recording is very difficult to catch, but it is clear that the gods are being entreated for their forgiveness, as the beginning

20 Like the rajah, the melodically more elaborated sections (lagu) in the pantun recitation would seem to have been suitable for such 2-4 minute recordings on wax cylinders. Weintraub (1990) presents a musical analysis of several lagu sung by Enjum from Ujungberung in the 1980 os.

21 Cod. Or. 8952, A: 830-834, to be found on the Internet of the Leiden University Libraries, https://catalogue.leidenuniv.nl . 


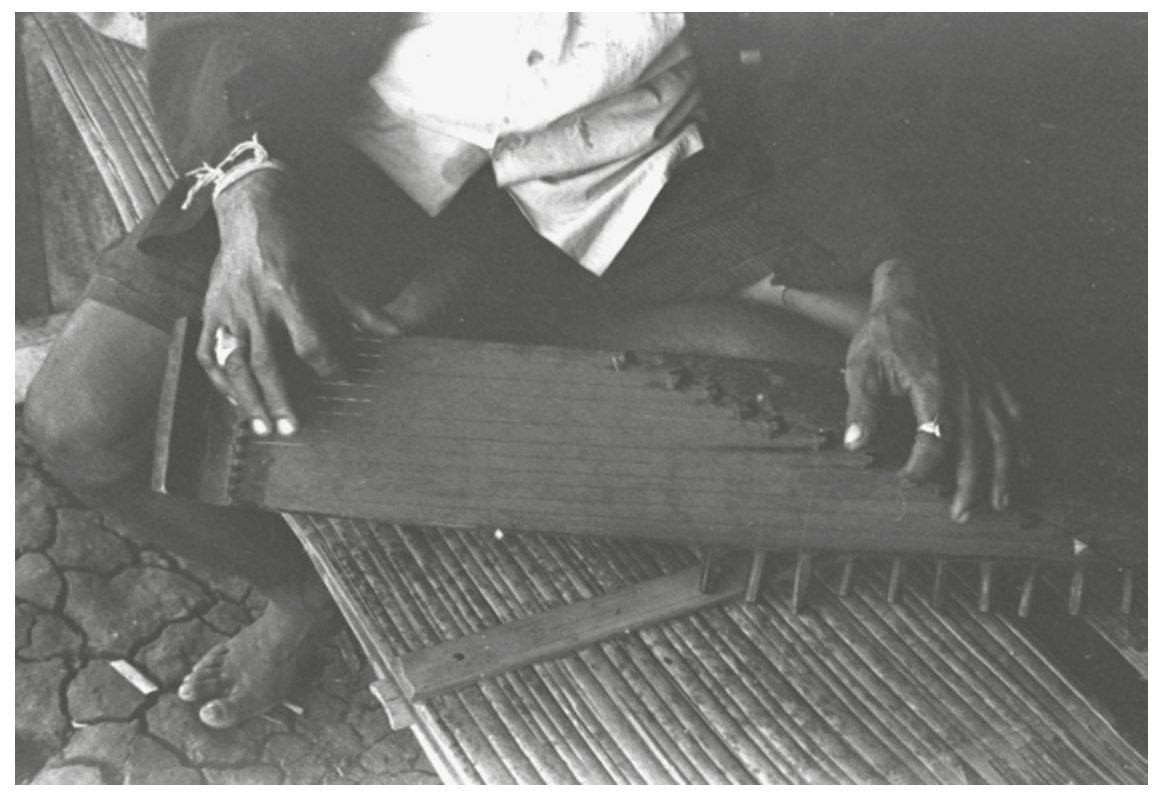

FIGURE 44 Hands of Yanci from Cikadu, Kanékés, who is playing kacapi zither when recorded in Kompol by the author, 27 July 1976

runs: 'I beg forgiveness/from above, from the ancestors/the song of the gods descends/of the gods and goddesses [...] I beg forgiveness'.22 Musically the recitation definitely resembles the recitation of pantun stories (Van Zanten $a c$ cepted for publication).

In the 1970s Ajip Rosidi recorded thirty pantun stories on tape and transcribed and published the texts of about twenty stories, including three Baduy stories (Rosidi 1973). ${ }^{23}$ In his introduction to the pantun story Buyut Orényéng (Sajin 1974), Rosidi is very critical about the quality of the recorded stories performed by the Baduy bards Sajin (two stories) and Yanci (one story). He did not include a summary of the Buyut Orényéng story in this publication because 'the summary of the story Lutung Kasarung [Sajin 1973] that I made the other day was more based on a reconstruction in my own imagination. Many parts

22 'Pun! Sapun!/Ka luhur ka sang rumuhun/Ka handap tembang batara/Sang batara sang batari [...] Amit ampun ...' Compare also Pleyte (1907: 30) who gives similar lines in the rajah of a pantun story.

23 It is not clear where these important audio recordings are kept at present (November 2019) and what the quality of the recordings is after some forty-five years. The most likely places seem to be either the personal archive of Ajip Rosidi or the University Library in Leiden/KITLV collection. However, neither Ajip Rosidi nor Leiden University Libraries in Leiden know the present location of the tapes. 
that did not connect, or were not logical, I made logical and related. Surely, such work cannot be validated'.

In the 1980s, when I allowed Mr Moh. Kosasih Atmadinata († 2002) listen to my recording of the Lutung Kasarung story performed by Sajin in 1977, he also said that he could not make much sense out of the story. It is possible that this difficulty arises because 'the sentence structure of the Baduy language is different to that of ordinary Sundanese and is therefore difficult for people from outside the Baduy area to understand' (Hamidimadja 1998: 18).

Difficulties in understanding the Baduy properly were reported by Blume as early as 1822. In his journey to the Baduy area, he was accompanied by a Sundanese guide, 'a sub-demang [kind of police officer], who had learned a little of the [Baduy] dialect through his earlier contacts'. This guide had 'difficulties in translating the answers given by the Baduy into Malay with the requisite accuracy' (Blume 1993 [1822]: 37). Van Hoëvell (1845: 409-410) confirmed the difference between the Baduy language and the surrounding Sundanese by citing Blume, adding the remark: 'It is Sundanese as spoken in the mountains of Banten, but mixed with words which are not used by the other population'.

Audio(-visual) recordings, especially the digitalized copies which can easily be played repeatedly without affecting the quality of the recording, can be a great help in solving the problem of our still limited understanding of pantun texts and music. Undoubtedly there are audio or audio-visual recordings of Baduy music, possibly including pantun, in personal archives in Indonesia. In the 199os, I did hear recordings of the kacapi player Yanci (Figure 44) at the home of the late Enoch Atmadibrata (1927-2011). Furthermore, the late Atik Soepandi (1944-2004) also told me that he possessed recordings of Baduy music. As should the Rosidi recordings from the 1970s, before the reels and cassette tapes have decayed entirely and become useless, these audio (visual) recordings should be digitalized and kept safely in a public library or some other public institution. A table with the audio/audio-visual recordings of the Sundanese pantun of which I am aware is presented in Van Zanten (2016a: 428-429).

The following sections, besides talking about some anthropological and musicological aspects of my own audio-visual recordings of Baduy pantun, also briefly discuss a few passages from the beginning (rajah) of these recordings. Facing methodological difficulties similar to those about which Ajip Rosidi spoke, I hope that my attempts will inspire others to do further research and deepen our understanding of the Baduy pantun. Some of the pantun texts discussed in Section 6.5 were taken from the transcriptions supplied by Rosidi's project mentioned above, like Sajin (1974). If not stated otherwise, the texts were transcribed from the recordings by the present author. I mainly used Eringa $(1949 ; 1984)$ and sometimes the translations by Pleyte to check the (many) 
Baduy words that I did not know. I then consulted Baduy experts, mainly the pantun performer Anirah in 2016. I also discussed the texts with my assistant Mumu; for him the texts were also difficult to understand.

\subsection{Own Recordings and Observations of pantun Storytellers ${ }^{24}$}

My first audio recording of a Baduy pantun story was made in January 1977. After I had made my first recordings of Baduy music in and around Kanékés in June and July 1976, in September of that year a group of Baduy came to my house in Jakarta, where I recorded the angklung ensemble, and the calung and gambang xylophones. I learned that the angklung could not be played in Kanékés in June and July that year, as the season for angklung was closed at that time and had opened again 20 August 1976. I had told my Baduy contact Talsim from Gajéboh that I was also interested in recording a pantun story.

In the afternoon of Saturday 8 January 1977, Talsim arrived at my house in Jakarta with the pantun bard Sajin, who was going to perform the Lutung Kasarung story. Sajin said that he then was about fifty years old (that is: born around 1927) and that he lived in the Outer Baduy hamlet Cisadané, about $1 \frac{1 / 2}{2}-2 \mathrm{~km}$ northwest of Cikeusik. Sajin was the teacher of another Baduy bard Yanci, who lived in Cikadu, about $2 \mathrm{~km}$ north of Cisadané. In July 2016 the storyteller Anirah told that Sajin was also known as Aki Janggot ('Grandfather Beard') and that he was one of the six pantun teachers at his time (see further Van Zanten 2016a: 418, footnote 29). For this performance Sajin had borrowed a small Baduy kacapi with eleven strings, made of white lamé wood, from Bernard Suryabrata. Ajip Rosidi has said that in August 1971 Sajin refused to play on a zither supplied by the organizing Proyek Penelitian Pantun dan Folklor Sunda, because it was not a kacapi, but 'a siter [flat zither], which had more than nine strings'; he only used kacapi pantun with nine strings (Sajin 1973: II). Possibly Sajin also had problems with the fact that the flat siter was not white, but varnished (brownish-yellow; see also Section 7.4).

After having a meal together, we began preparations for Sajin's performance. Sajin had asked for a white cloth to be erected like a tent or a baldachin (lawon bodas) under which he would recite the story. One of our bed sheets was used to construct the lawon bodas baldachin. A towel rack on a table and two music stands in front formed the somewhat unstable supporting structure for the white bed sheet. Talsim and Sajin had not brought an offering (sasajén) with 


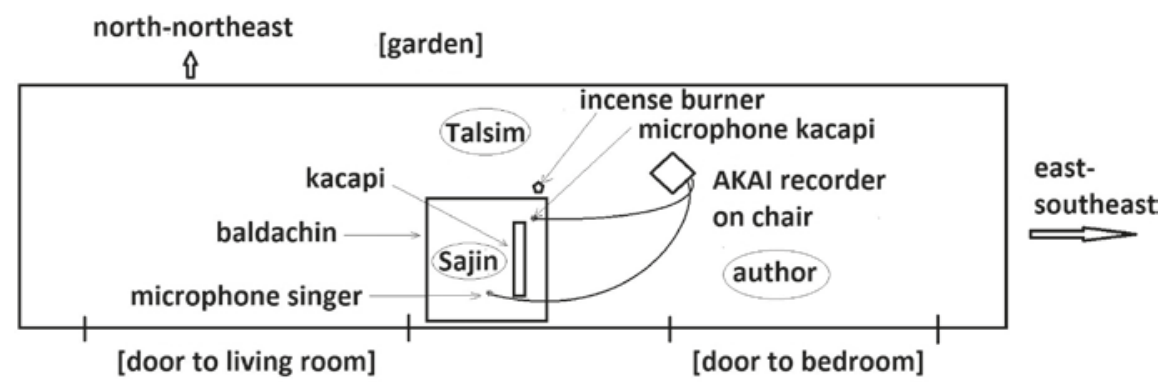

FIGURE 45 Position of the pantun bard Sajin on the floor under a white 'baldachin', facing east-south-east when recording the Lutung Kasarung story. Jakarta, 8-9 January 1977

them and had not asked me to supply the components of an offering, among them different kinds of rice, sugar, biscuits, cigarettes and sweets. Pantun performers whom I recorded later always had an offering in front of them before commencing the recitation, including the former Baduy Sawari (below; see also Van Zanten 1993: 145, 2012: 130.)

This 'baldachin' was placed on our veranda and as he performed Sajin sat on the ground under this baldachin with the zither on his lap. The incense burner (padupaan) was placed on the ground between Sajin and Talsim: see Figure 45 .

The performance began at 20.20. Incense was burnt and Sajin murmured a prayer (jampé) for about 2-3 minutes. Then he began to sing the introduction (rajah) to the pantun recitation which is more or less the same for all pantun stories sung by a particular singer. The beginning of the Baduy rajah will be discussed in more detail in Section 6.5 below. Once in a while Sajin smoked, drank coffee and adjusted the tuning of the kacapi. At the end of the performance, Talsim said that after the end of January the pantun and all types of music could not be played for three months, during the fasting period (kawalu) in the Baduy months Kasa, Karo and Katiga. A short summary in English of the Lutung Kasarung story in the non-Baduy, Priangan, version may be found in Van Zanten (2016a: 430-432).

My second audio-visual recording of a Baduy pantun was in 2003 and it was the story Paksi Keuling recited by Sawari (ca. 1948-1 June 2016). He had been an Inner Baduy, living in an Outer Baduy hamlet Cikadu, before he migrated to the area outside Kanékés in the late 1970s. Consequently he no longer belonged to the Baduy community at the time of recording. ${ }^{25}$ Although he could play the kacapi, as I had recorded his playing and singing with kacapi in 1992 
(Van Zanten 1995: 530-531, 541), on this particular evening Sawari did not accompany himself on a kacapi.

On Wednesday evening 2 April 2003 between 20.10 and 21:50, Sawari performed part of the pantun story Paksi Keuling in the house of another former Baduy Nalim in Margaluyu, Rangkasbitung. ${ }^{26}$ Sawari stopped the performance regularly and began to explain the story. Before the recitation commenced, incense was burnt, an offering (sasajén) was made and a magical formula (jampé) was murmured. For the offering Sawari had asked us to buy the following ingredients: 2 litres uncooked rice, 1 kilogram white sugar, 5 bags of tea, 5 eggs, 9 bags of coffee, 5 buns, 1 packet Marie biscuits, 1 bottle with limun (kind of soft drink), 3 wafers, 5 pieces of Sukro (krupuk, chips, usually made with shrimps), 10 pieces of Sukro kecil (small krupuk chips) and peppermints. These ingredients were bought in the local shop for a total of Rp 23,000 (about € 2.50, US\$2.72).

Sawari had also asked for some yellow cooked rice (nasi kuning) and a packet with ten cigarettes, which were supplied. Only some of these ingredients of the offering were placed on the ground as he recited (see Picture 1 in Van Zanten 2012:130). For instance, the white sugar, the cooked and uncooked rice, and the bags of coffee and tea were missing. As usual, the offerings were taken home by the performer after the performance.

I recorded and documented this performance on minidisk and digital video camera. Unfortunately my video recordings turned out very dark. One of my Leiden students, Nanni Tempelman, who also recorded this recitation on digital video, allowed me to use her film material for analysis. Also present was Mumu Zaénal Mutaqin, who assisted me in transcribing our discussions from the recording on minidisk; see also Section 3.4-3.5. A short summary in English of a Baduy version of the Paksi Keuling story, based on existing literature, can be found in Van Zanten (2016a: 432-434).

\subsubsection{Direction that the Pantun Performer Should Be Facing}

Sawari told that the direction the performer should face depends on the night on which he performs, if the performance is for planting rice or curing the rice from diseases, that is, connected to the goddess of rice Déwi Asri. ${ }^{27}$ This recitation took place on Wednesday night (malam Kemis). The storyteller Sawari faced south-west and did not fully face the audience in the room (see Picture 1 in Van Zanten 2012: 130). When sowing rice in the daytime on

26 Nalim is the eldest son of the former Baduy secular village head, Samin, who migrated to Cipangembar in 1978. See also Section 5.4.

27 The last part of this sentence is important, as discussed below, and was unfortunately not mentioned in my article on Baduy pantun (Van Zanten 2016a: 421-423). 
TABLE 8 Direction that the pantun performer is facing in relation to the night on which he is performing for planting rice and curing the rice from diseases

Direction Night on which the pantun story is told Day of planting according to rice (Sawari 2003)

$\begin{array}{lll}\text { Sajin } & \text { Sawari } 2003 & \begin{array}{l}\text { Sumardjo } \\ (2013: 8)\end{array}\end{array}$

\begin{tabular}{|c|c|c|c|c|}
\hline North & & $\begin{array}{l}\text { Friday night/malam } \\
\text { Saptu }\end{array}$ & Friday night & Saturday/Saptu \\
\hline Northeast & & $\begin{array}{l}\text { Saturday night/ } \\
\text { malam Ahad }\end{array}$ & $\begin{array}{l}\text { Saturday } \\
\text { night }\end{array}$ & Sunday/Ahad \\
\hline East & $\begin{array}{l}\text { Saturday } \\
\text { night }\end{array}$ & $\begin{array}{l}\text { Sunday night/ } \\
\text { malam Senén }\end{array}$ & not used & Monday/Senén \\
\hline Southeast & & $\begin{array}{l}\text { Monday night/ } \\
\text { malam Salasa }\end{array}$ & $\begin{array}{l}\text { Wednesday } \\
\text { night }\end{array}$ & Tuesday/Salasa \\
\hline South & & $\begin{array}{l}\text { Tuesday night/ } \\
\text { malam Rebo }\end{array}$ & $\begin{array}{l}\text { Monday } \\
\text { night }\end{array}$ & Wednesday/Rebo \\
\hline Southwest & & $\begin{array}{l}\text { Wednesday night/ } \\
\text { malam Kemis }\end{array}$ & $\begin{array}{l}\text { Tuesday } \\
\text { night }\end{array}$ & Thursday/Kemis \\
\hline West & & $\begin{array}{l}\text { Thursday night/ } \\
\text { malam Jumaah }\end{array}$ & $\begin{array}{l}\text { Thursday } \\
\text { night }\end{array}$ & Friday/Jumaah \\
\hline Northwest & & not used & not used & not used \\
\hline
\end{tabular}

Thursday (dinten Kemis, hari Kamis), Baduy also have to commence sowing in the south-western corner of the field and proceed in a clockwise direction, the direction in which the mythical snake moves (gilir naga). Sawari told that the relationship between the day and direction the storyteller should be facing is as presented in Table 8.

Garna (1988: 261, 264) gives a similar relationship between day and 'appropriate' direction to that obtained from Sawari in 2003, except in his case north was the direction omitted; instead, the direction north-west was used on Friday night/Saturday. In his book on symbols in Sundanese pantun stories, mentioned above, Sumardjo (2013: 8) does not explain how he obtained his information on Baduy pantun which differs considerably from my field data and those of Garna, and this does not make sense to me. In the schedule, Sajin is facing east on Saturday night (malam Minggu)], which he and Talsim had said 
was the right direction in 1977. Following Sawari's scheme he should have been facing north-east on Saturday night.

Sawari's scheme, including the relation with the planting of rice, has been confirmed by several other Baduy. First of all the storyteller Anirah confirmed this gilir naga scheme on 10 July 2016 for pantun storytelling concerning the rice. Karamaén from Cibéo added that this gilir naga scheme was also followed when performing the pantun for hunting: Buyut Orényéng. These performances take place in the 'time devoted to Déwi Asri' (A2016-1: 40).

Further, on 3 April 2003 the secular village head (jaro pamaréntah) Daénah, who held office from 1997 to April 2015, and some other people, including the kacapi player Satra, explicitly confirmed that the planting on a Thursday should begin in the south-western corner and continue in a clockwise direction (gilir naga). Later, on 13 December 2013, Aki Daénah, the father of Daénah, also confirmed the relationship between the direction and day of a performance as given by Sawari. He also confirmed that one direction is definitely not used, but he was not sure whether it was north-west or north.

The direction in which the mythical snake moves (gilir naga) is also observed during the ceremony of the betrothal (ngarérémokeun) of the rice goddess Nyi Pohaci Sangiang Asri to the earth, Partiwi. The angklung players walk around a basket of rice in a clockwise circle (gilir naga), that is, the 'holy' direction in many parts of Asia. When angklung players are singing songs purely for entertainment, they walk around a circle in an anti-clockwise direction: the direction in which the koréd knife (Figure 23) moves when it is used for weeding (palélé koréd); ${ }^{28}$ see also Geise (1952: 34-40) and Van Zanten (1995: 533-537). This anti-clockwise direction was also called mapag naga, to meet the naga snake, by Rasudin (A2013: 27).

Besides the pantun performances recorded outside Kanékés, Sajin in 1977 and Sawari in 2003, I have heard pantun stories performed inside Kanékés in 2014 and 2016 without being able to record the performances. The pantun performances in July 2016 were in the context of circumcision rituals and have been described in Sections 4.4 and 4.5. The 2014 one was at the inauguration ceremony (nukuh lembur) of the hamlet Campaka, near Kaduketug in Kanékés,

28 The koréd is a small hoe which looks like a short sickle with a broad blade; see Figure 23 in Section 2.7. Held in the right hand when weeding, it moves in anti-clockwise direction. Budi (2015: 239-240) mentions the terms ider naga and ider munding that are used for a clockwise and and anti-clockwise circular movement around Subang. According to Dinda Budi, in the ngaseuk rice ritual in Ciptagelar it is only the clockwise direction that is used when planting. Zoetmulder (1982) mentions several Old Javanese manuscripts in which the Sanskrit verb ( $m$ ) apradakșina, 'to go around or turn in a clock-wise direction' is used. 
from about 21:45-24.15 in the evening of Wednesday 4 June 2014 (day 9 of the Baduy month Kalima). See Campaka hamlet in Figure 46 and the making of sweets in preparation for the inauguration in Figure 47. On this occasion the story Langga Sari was performed by the storyteller (Ki Pantun) Anirah from Kaduketer 2. I was not allowed to be present in the house in which the performance actually took place in of the presence of Baduy elders (kokolot). My attendance was restricted to the veranda of a house opposite that in which the pantun story was being performed. Although I could not see what was really going on and was not allowed to make audio-visual recordings or take photographs, the singing was clearly audible and I noticed that the musical manner of performing was very similar to that I had heard and recorded from Sajin in 1977 and Sawari in 2003.

The next day in 2014 the former secular village head Asrab (1990-1994) told me that the pantun storyteller Anirah had also used a kind of tent or baldachin, as Sajin had done in 1977. Asrab said that it was made of boéh larang cloth, ${ }^{29}$ but when I asked he replied that he would not have called this a lawon bodas: a lawon bodas construction was used for circumcisions and was larger than the construction used by Anirah. In this respect compare also Jacobs and Meijer (1891: 71), who describe the use of white cotton for covering the inside of the temporary awning (papajangan) under which the teeth of Baduy girls and boys are filed.

At circumcisions (sunatan) and human weddings (nikahan, kawinan), a pantun storyteller should be facing the south, the 'holy direction', according to most of my informants, including jaro Asrab, carik Sapin, Arpani from Kadujangkung and musician Karamaén from Cibéo (A2016-1: 37-38, 40). This is different from the rituals for the rice goddess Nyi Pohaci (Déwi Asri) and for hunting, when the position of the pantun follows the holy snake' (gilir naga) as mentioned above and summarized in Table 8. A neighbour of Anirah in Kaduketer 2 expressed this as follows: if there are elders (kokolot) present, the pantun performer faces the south, if it is performed on the fields as medicine for the rice (pengobatan padi) it follows the gilir naga (A2016-1: 38). This confirms what was told by the secular village head Saijah (see Section 4.1): there is music for the gods, and specifically the rice goddess Nyi Pohaci Sangiang Asri and her children, and music for human beings during the ritual meals at feasts (hajat(an)), like weddings and circumcisions (A2016-1: 1-2). Angklung and pantun may be used for both music for the gods and music for human beings, but keromong can only be used for human beings. 


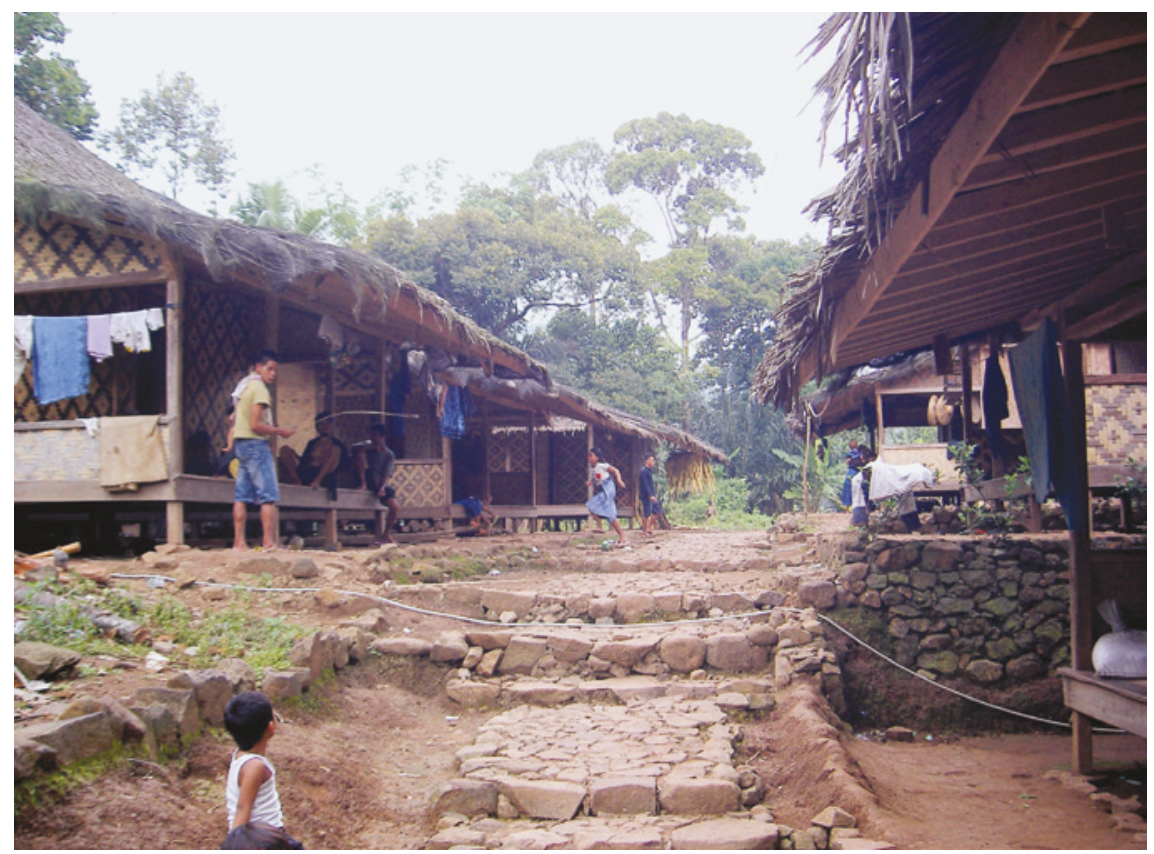

FIGURE 46 Campaka hamlet on the day of inauguration in the evening, 4 June 2014

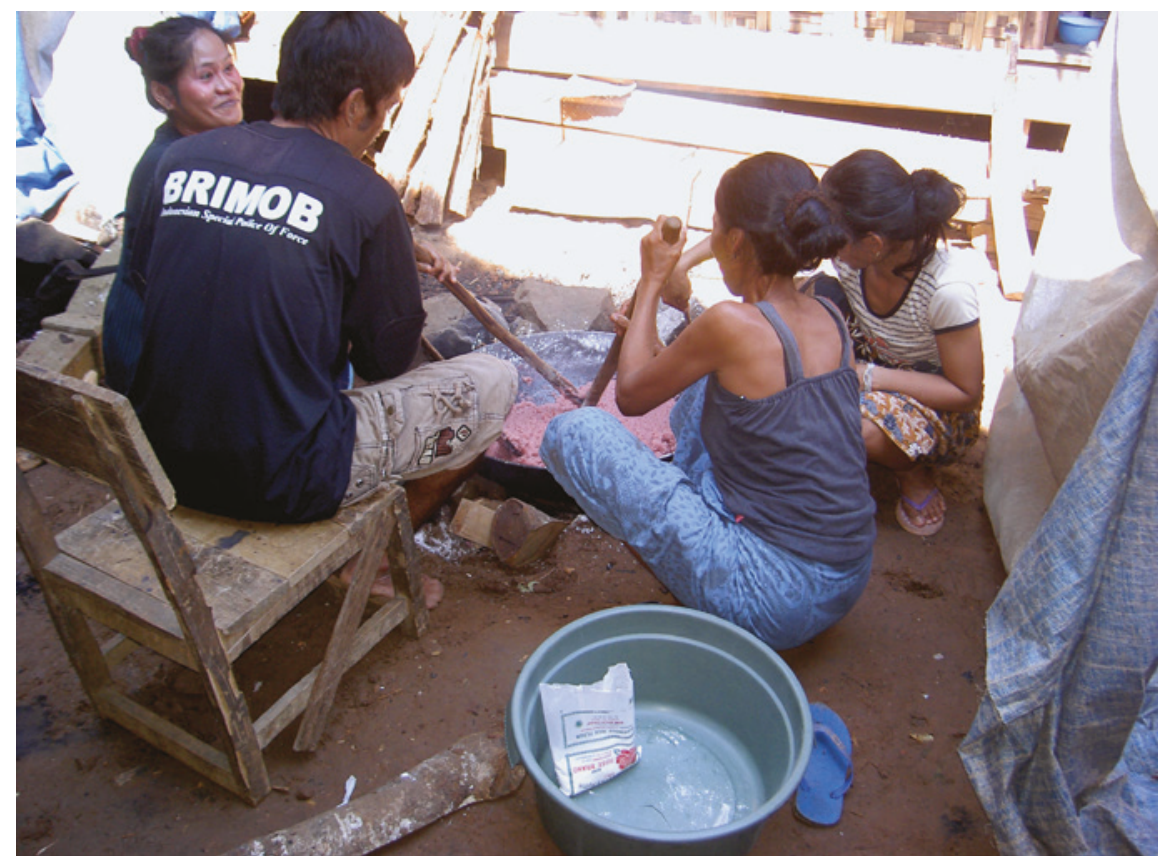

FIGURE 47 Making of wajik sweets from glutinous rice flour, bought in plastic bag, coconut milk and sugar for the coming inauguration ritual (nukuh lembur) in Campaka, 30 May 2014 
The pantun performer Ayah Anirah was the only one who said that the fixed position of the pantun storyteller at circumcisions was such that he was facing the west, instead of south. He also said that at (human) weddings the pantun player follows the gilir naga on the three possible performing days: malam Kamis (Wednesday evening-Thursday morning, facing southwest), malam Senén (Sunday evening-Monday morning, facing east: not used?) and malam Selasa (Monday evening-Tuesday morning, facing southeast) (A2016-1: 44). I very much doubt this information by Ayah Anirah, as it contradicts his own statements and what several other important informants have said.

\subsection{Recited Text and Performing Aspects of Pantun Recitation}

In this section I shall restrict myself to discussing small parts of the texts recited by Sajin and Sawari, mainly from the opening of their pantun performance, that is, the rajah (pamunah), in a modest attempt to describe the differences in performance styles of the Baduy bards and pantun performers in the regions east of Kanékés.

A pantun recitation begins with a standardized opening (rajah, rajah pamunah) and the recitation might end with a rajah pamungkas. Looking at the full pantun texts obtained by Pleyte and the project of Rosidi, it appears that the rajah of a particular bard remains fairly constant and is independent of the story being told. Be that as it may, unquestionably we can conclude that there can be considerable divergence between different performers. This is confirmed by the findings of Weintraub (1990) and Van Zanten (1993). I have also pointed out that in his rajah the pantun performer Enjum from Ujungberung, Bandung, apparently followed the tradition presented in Pleyte (1910: 135-136) and Eringa (1949: 121-130): an eastern Priangan tradition from Bandung to Ciamis, South Cirebon. For instance, on 5 September 1981, Enjum began his rajah in the Lutung Kasarung story as presented in Table 9 (Van Zanten 1993: 156). ${ }^{30}$

The Baduy rajah follow another tradition. This is also indicated by the different musical aspects of the performance styles. In Van Zanten (1993: 147-148) I noted that in Sajin's recitation, the dramatic effects are less pronounced than in the performances of Enjum. Sajin's virtuosity on the accompanying kacapi is far less than Enjum's, and sometimes he does not touch the instrument for

30 The English translation of the Sundanese text here presented is slightly different from the 1993 one. 
TABLE 9 Beginning of rajah as recited by Enjum (Bandung) in the Lutung Kasarung story, 5 September 1981

$1 \quad$ Astagfirullah al adzim (5x)

2 Bul kukus mendung ka manggung

3 Nyambuang ka awang-awang

4 Ka manggung neda papayung

5 Ka pohaci neda suci

$6 \quad$ Ka déwata neda maap

7 Kuring rék diajar kidung

8 Nya kidung carita pantun

9 Ngahudang carita anu baheula

10 Nyukcruk laku nu rahayu

11 Nyilokakeun

12 Mapay lampah nu baheula
Heaven forbid!

I burn incense, in dark clouds ascending.

It rises and spreads in the air,

High up in the air, to ask protection.

To the heavenly nymphs to ask sanctification,

To the gods to ask pardon.

I want to perform singing,

To sing a pantun story,

To re-create a story from the past,

Following the beneficial actions,

In siloka (symbolic) form,

To follow the course of actions of the past.

many minutes at a stretch. On the other hand Sajin's speed of recitation varies much more than Enjum's speed; from very slow to very fast. Listen to $<\mathrm{AV}_{12}>$ $\left(1^{\prime} 45^{\prime \prime}\right)$ with text transcribed in Table 10 and items 1 and 2 on the Demonstration cassette tape with Van Zanten (1989). See also the text and music transcription of a small section of Sajin's recitation in Van Zanten (1995: 529-530, 540-541).

In 2016 the pantun performer Ayah Anirah called the slow and drawn-out recitation 'haleuang pada cirambay', literally, 'singing with tears in your eyes'. He called the fast, hurriedly (kenceng) and animated singing 'haleuang pada ramé' (A2016-1: 67, Audio recording D 2016-15: 1ho6m-1hom). Anirah demonstrated these two ways of singing that are given in the following audio recordings: (1) reciting (haleuang) in the cirambay (drawn-out) way in $<\mathrm{AV}_{13}>\left(2^{\prime} 15\right.$ ") and (2) reciting in the pada ramé (animated) way in $<\operatorname{AV}_{14}>(23 ")$. At the end of $<\mathrm{AV}_{13}>$ Anirah says that the pada ramé singing is twice as fast as the cirambay singing ('dua kali lipat').

In 2016 Anirah also said that Baduy bards use five different voice types for the characters in a story. In the pantun Langga Sari Matang Jaya you have the character Oa (a kind of grey monkey - gibbon) with a particular voice and his elder companion Kai Lurah Pajajaran (the Honourable village head of Pajajaran) who has a different voice and talks differently. This village head of 
Pajajaran often laughs. Anirah demonstrated this laughing in $<\mathrm{AV}_{15}>(23 ")$ and he also demonstrated the voice of Kai Lurah Pajajaran's wife in $\langle\operatorname{AV} 16>(11$ ").

In the rajah, both Sajin (in 1977) and Sawari (in 2003) describe their singing as kawih, not as kidung, which is commonly used in the Priangan tradition, as represented by the above example of Enjum from Bandung. Presumably, $k a-$ wih is the oldest Sundanese term known for singing/song or vocal music. The Sundanese kidung is an incantation to avert illness, theft and other possible evils when venturing into places which might harbour spirits (Eringa 1984; Van Zanten 1989: 15, 17-18). See also my remarks about the text of the song Kidung Rahayu in Section 7.3.

In my recording of 1977 Sajin began his rajah as presented in Table 10 (starting with line 3). The text was transcribed from the recording; the transcribed text and translation are 'approximate' and should be looked at critically. The sections marked by plus signs at the beginning and end $(+\ldots+)$ indicate melodically more elaborated phrases ('songs') that are embedded in the recitation.

In line 4 of Table 10 Sajin mentions the 'animated' (pada ramé) singing that was demonstrated by Anirah's singing in $<\mathrm{AV}_{14}>$ in 2016. Garna (1988: 122, 130,167 ) remarks that dunia ramai (ramé) is used to indicate 'the world outside Kanékés that is ruled by the kings (raja-raja) of Banten, such as found in the mythology and Baduy folklore, Budak Buncireung ...' According to Garna 'orang ramai' (orang ramé) is used for those people who deal with outside matters, that is, matters concerning the 'outside rulers' that are dealt with by the jaro pamaréntah and the tanggungan jaro duabelas. In the context of a pantun recitation, pada ramé singing seems to mean: singing that is not immediately connected to the ritual context, distracts from asceticism, and is concerned with worldly matters. See further below.

In lines 6-8 Parungkujang is the name of a kingdom near the mountain $\mathrm{Ku}-$ jang and mentioned in the story Déwa Kaladri as notated by Pleyte (1912: 267291) and nowadays a village bordering west of Kanékés (see also below). Parung is a shallow part in the river, where you may cross; kujang is a knife that is used by the Baduy to clear the fields. In west Java it is also used as a symbol of Sundanese identity.

In my recording of 2003 Sawari began his rajah as presented in Table $11 .^{31}$ In lines $21-25$ of Table 11 the Sundanese word méga means 'cloud'. In Section 6.2 was mentioned that in the pantun stories it is also used as a kind of title, like in the name for a man Méga Kumendung that occurs in the story Paksi Keuling (Beberapa cerita rakyat Baduy 1975: 20; Jacobs and Meijer 1891: 163, 
$+\ldots+$ means: a melodically more elaborated section ('song' in recitation); $<\mathrm{AV} 12>$; see also Music Transcription $\operatorname{Tr} 5$ below.

[... a few seconds missing in

recording, probably:

1 Mun cik diajar ngawih

[Well, if I want to start singing

2 Kawih urang kaulinan (?, Sajin My singing is playing] 1974: 1)]

3 [o:oo] [...] Kawih sindir

Singing of allusions in bangbalikan form bangbalikan

4 Kawih sendén pada ramé

5 Kawih tumpang

6 Cénah Parungkujang

Singing by the female singer-dancer at festivities

7 Lain tumpang Parungkujang

8 Tunggal a tumpang Parungkujang This singing is an additional gift from Parungkujang Well, not an additional gift from Parungkujang The contribution from Parungkujang strikes [us] [?]

9 Tunggal tumpanganeun kawih This singing is meant to hit

10 Nguang-ngiung ${ }^{b}$ nabeuh irung Whining through the nose

11 Nguak-nguik nabeuh ceuli

12 Nabeuh irung cikiblungan ${ }^{\mathrm{c}}$

13 Nabeuh ceuli kakawihan (means) coming incoherently to the ear To murmur unintelligibly (is like) tapping the surface of the water with your hands The singing touches the ear

14 Kawih teu puguh mubusan ${ }^{\mathrm{d}}$

15 +Kawih tatambalan ${ }^{\mathrm{e}}$ tiiseun

16 Paranti ngasuh nu pundung

17 Paranti ngambat nu leumpang+ Incoherent song will not sink in properly +Singing is a medicine to calm down A means to look after those who are angry A means to get the attention of those who are leaving+

18 Paranti ngalega nu ngalingsig

19 Paranti mangdaya tineung [1:45] A means to comfort those who have been ill A means to strengthen our feelings of longing $[\ldots]$

a I take it that tunggal is used here as teunggeul, to hit, to strike(Eringa 1984).

b Nguang-nguik?

c In Sajin (1974:1) is given 'cicimplungan'; this is definitely not what is said in my recording.

d In Sajin (1974:1) one of the sentences reads: 'Kawih teu puguh buusan'.

e Tatambalan is 'that what has been repaired or mended' (clothes); tatamba (from tamba, medicine): to use medicine or to search for cure. 
$+\ldots+$ means: a melodically more elaborated section ('song' in recitation)

$1 \quad$ [1:0o] Latih kurang diajar ngawih

2 Kawih sindir bangbalikan

$3 \quad$ Kawih sindir [sudat?] manik

4 Mamah sendén pada ramé

$5 \quad$ Nguak-ngiuk nabeuh irung

$6 \quad$ Nguak-nguik nabeuh ceuli [1:31]

7 [Unggah dina?] babasanana

8 Hujan poyan horéng

$9 \quad$ Pongporang dipotong-potong

10 Dijieun rakit untang-anting

11 Kapit ungkur amis
With insufficient training I practise singing

Singing allusions in bangbalikan form

Singing of allusions is cutting the jewel

Mother female singer-dancer at festivities

Mumbles incoherently through her nose

And it incoherently strikes [our] ears

A figure of speech comes to my mind:

Rain during sunshine, say!

The pongporang tree is cut into pieces

A raft is made to go there and back

It is swung nicely in opposite directions [?]

12 Mata(k) +paranti mupulihkeun

13 Paksi Keuling di Pakuan

Pajajaran

14 Pasilir-silir ku angin

This leads to +a means to report on

Paksi Keuling in Pakuan Pajajaran

The place where the soft wind blows

15 Kakebut-kebut ku ombak banyu Undulated by the waves, say!+ horéng $+[2: 25]$

16 Nya kéong na paké pasang

17 Pasang duaanana

18 Na pasang duaan

19 Guru ahung Guru ahung

20 Basa [baku?] ka luhur ka manggung

21 Ka méga beureum ka méga hideung

22 Ka méga [Pacik?]

23 Méga Si Karambangan

24 Ka méga Si Karambangan

25 Ka méga Si [Gereg?]

$26 ?$

$27 \quad$ ?

28 Kasih kawenang-wenang
The snail takes a partner

A couple, both of them

A couple of two

Teacher, hail! Teacher, hail!

The usual language is going up into the air

To the red cloud to the dark cloud

To the Pacik cloud

The cloud Karambangan

To the cloud Si Karambangan

To the cloud Si Gereg

?

?

Grant me permission 
TABLE 11 Rajah of Paksi Keuling by Sawari, May 2003 (cont.)

\begin{tabular}{|c|c|c|}
\hline 29 & $\begin{array}{l}\text { Nyaritakeun lalakon Paksi } \\
\text { Keuling }\end{array}$ & To tell the story of Paksi Keuling \\
\hline 30 & $\begin{array}{l}\text { Lalakon baheula diciptakeun } \\
\text { ayeuna [2:59] }\end{array}$ & $\begin{array}{l}\text { A story of the past that is now }[\mathrm{re}] \\
\text { created }\end{array}$ \\
\hline 31 & Bisi ngebut nu sasih & Possibly I will mention the month \\
\hline 32 & $\mathrm{Ku}$... pamali? .. alus & ... forbidden? ... \\
\hline 33 & Nyebut ngaran, ngaran pamali & To tell the names, the forbidden names \\
\hline 34 & Ménta agung paralun & I ask forgiveness \\
\hline 35 & Panjang hampurana & Full forgiveness \\
\hline 36 & Nya lalakon carita pantun & As it is a pantun story \\
\hline 37 & Lalakon Paksi Keuling & The story of Paksi Keuling \\
\hline 38 & Ratu ti Pakuan & King from Pakuan \\
\hline 39 & $\begin{array}{l}\text { Ménak di Pajajaran, horéng } \\
{[3: 23][\ldots]}\end{array}$ & $\begin{array}{l}\text { The nobles in (the) Pajajaran } \\
\text { (kingdom), say! }\end{array}$ \\
\hline
\end{tabular}

Pleyte 1912: 377). Danasasmita and Djatisunda (1986: 77) state that there are 18 levels of 'nature' (alam) or 'worlds' (dunia) between the upper world (buana nyungcung) and the central or human world (buana pancatengah) and the lowest levels, that is nearest to the human world, are called Méga Munggul, Méga Malang, Méga Beureum, Méga Si Karambangan, Méga Si Kareumbingan and Méga Si Antrawela.

From Tables 10 and 11 it becomes clear that the texts of Sajin's and Sawari's rajah use many similar words and are different to the text of a rajah in the Priangan pantun tradition represented by Enjum in Table 9. I have not heard or seen Sawari's first two words in the first sentence, latih kurang, in the transcribed rajah texts of other Baduy storytellers. ${ }^{32}$ By adding these two words, Sawari reinforces the idea that he is not a competent performer: latih kurang diajar ngawih, 'practising singing without sufficient training ...' Possibly by using this apologetic statement, Sawari wanted to express his idea that, because he had lived outside Kanékés since the late 1970s and had been surrounded by Muslims, he lacked sufficient practice, because he was not often asked to perform pantun stories. He describes himself as someone just learning and practising: he is 'being taught

32 See, for instance, the two Baduy pantun recordings by Rosidi which commence Urang diajar ngawih, 'I shall practise singing' (Sajin 1973: 1) and Mun cik diajar ngawih, 'Now then, I shall practise singing' (Sajin 1974: 1). 


\begin{tabular}{lll}
1 & Hayang agung paralun & I beg pardon from the gods \\
2 & Menta panjang pangampura & I keep asking forgiveness \\
3 & Hampura sangiang sora & Forgiveness [from] the god of the voice \\
4 & Tanda ja kami diajar & It is a sign that I am learning \\
5 & Mun bohong nyari-nyari & When I lie in search for the truth \\
6 & Mun bohong sakala kapeung & When I sometimes lie \\
7 & Asa mundur bebedugan & [It is like the removal of the drums \\
& & from the mosque \\
8 & Asa maling kanyaringan & It looks like a thief waking up?] \\
9 & Ulah nuding ka kacapi & Do not blame the kacapi \\
10 & Ulah ngabantah ka sora [...] & Do not blame the voice \\
\hline
\end{tabular}

to sing' (diajar ngawih). These words are used by all Baduy pantun storytellers; farther to the east they use words with a similar meaning, diajar ngidung (Eringa 1949: 138-9, 209; Van Zanten 1993: 156), also repeated in the example of Enjum above. They are asking themselves whether they are competent to tell a 'story from heaven'. In their sung opening (rajah) Baduy storytellers like Sawari also ask the forgiveness of the gods: 'Grant me permission to tell the story of Paksi Keuling, a story of the past which is now [re]created' (lines 28-30 in Table 11).

Sajin (1974:10, 11) twice presents a much stronger text, in which he tells that, because he is still learning, he may sometimes lie (bohong) when trying to get to the essence of the story; see Table 12.

Both Sajin and Sawari mention that the performer should not 'mumble incoherently through the nose', because 'incoherent song will not sink in properly'. I suppose this is also expressed by the words 'Singing of allusions is cutting the jewel' (sudat manik): the singing of allusions, often to express erotic feelings and love, is 'damaging' to the essence of a pantun story. In Sawari's version it is clear that it is the entertainment, the 'incoherent speech' of the 'Mother female singer-dancer at festivities' which the pantun performer should take pains to avoid. The pantun stories are more than just entertainment and the storytelling should be done in a proper way, that is, underpinning the duty to live an ascetic way of life. If this advice is followed, the pantun recitation will be a good medicine for the members of the audience: 'Singing is a medicine to calm down, A means to take care of those who are angry, [...], A means to intensify our feelings of longing. (Table 10, lines 15-19, <AV12>.)

Of particular interest is the passage in Sajin's rajah in which he talks about the former kingdom of Parangkujang: 'Kawih tumpang [...] Parungkujang'. (Table 10, 
TABLE 13 Metaphor of the false gong From Van Zanten 1989: 194, and recorded on accompanying cassette tape $\#_{1}$; listen to $\left\langle\mathrm{AV}_{17}\right\rangle$

$1 \quad$ [5:22] Goong di barat, goong di timur

2 Goong di kalér, goong di kidul

3 Goong pélog sosorogan

4 Goong sumbang pangrampogan

5 Paranti ngéléhkeun musuh

6 Lain éléh ku hadéna

7 Éléh ku sumbangna baé

8 Éléh deungeun-deungeun tamba [5:53]
The gong/gamelan in the west, the gong in the east

The gong in the north, the gong in the south

The pélog gong is out of tune

A false gong is at risk of being stolen

The means to beat the enemy

Will not fail if in good order

(But) will be defeated when out of tune

Fail because of strange medicine.

lines $5-8$; $<\mathrm{AV} 12>$.) This passage was also sung by the former Baduy Japar in 1911 (Pleyte 1912: 292): Kawih tumpang Parungkujang. These words might mean: 'Singing as an additional gift from Parungkujang' and this is presumably meant in a pejorative sense, namely: presenting an undesirable and moreover unsuitable type of singing. Parungkujang is the name of a kingdom near Mount Kujang, mentioned in the story of Dewa Kaladri noted by Pleyte (1912: 267-291). Another version of this story is known as Budak Buncireung or Budak Buncir; see, for instance, Geise (1952: 109-16, 176-81, 218-22, 239-42) and Hamidimadja (1998: 77-84).

The Baduy believe that when the time comes in which the relations between them and the outside world will deteriorate, the village of Kanékés will be attacked by the still existing village of Parungkujang which will be 'supported by the government' (Geise 1952: 115). Pennings (1902: 370) mentions that the people living in the vicinity of Kanékés were free to move around there to trade their wares; the highest spiritual leaders (girang puun) had even given their permission for the building of an Islamic settlement (ampian, ampéan) Cicakal in Kanékés, by the people 'from Parungkujang lying to the west of Kanékés. See also my remark about the period in April 2003 when the USA and the U K were about to invade Iraq. The Baduy feared that this could be the beginning of the third World War on religion, in which they might possibly be wiped out by the outside world (Van Zanten 2004: 141; see also Section 2.4). According to Anirah (A2016-1: 62), until this day Baduy people are not allowed to buy land in Parungkujang. If forced by economic reasons they may only temporarily work on land in Parungkujang. See also Bakels and Boevink 1988: 78). 


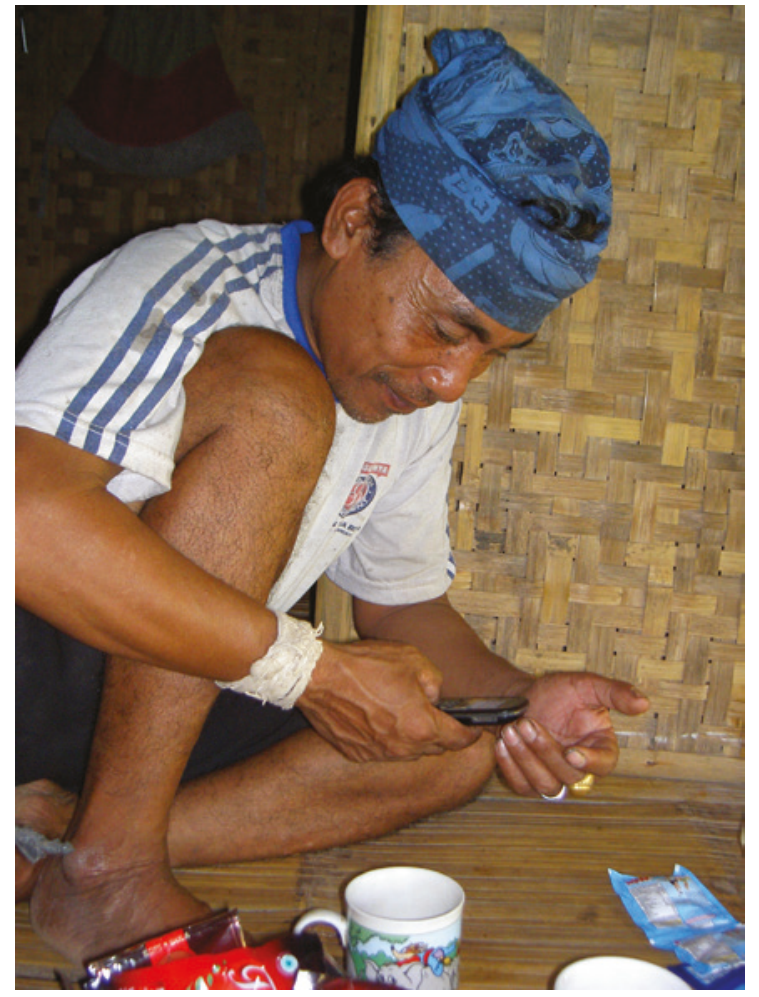

\section{FIGURE 48}

The pantun storyteller Anirah looks at a mobile phone in his house near the rice fields in Cikapék, outside Kanékés, 16 July 2016

This reference to a less beneficial way of singing (enunciating incoherently through the nose like the sindén with the gamelan and presumably the singing introduced from Parungkujang), contrasts with the (proper) pantun recitation is also found elsewhere in Sajin's 1977 recitation. He there uses the metaphor of a false gong or gamelan, standing for a king and his kingdom that are ill and in disorder (Table 13).

See further Sajin (1974:108) and Pleyte (1912: 316). I have pointed out that the false tuning of musical instruments (sumbang, which also means: incest) is a metaphor for human relationships which are fundamentally wrong. The false musical instruments indicate that the social order is disturbed and the society affected will fall apart (Van Zanten 1994: 88-90). It is therefore important that the pantun performer tells the story in the correct manner and that his instrument is properly tuned.

In July 2016 the pantun storyteller Anirah supplied texts for finishing a story (rajah pamungkas) and for continuing story after a break (A2016-1: 42-43). The rajah pamungkas (part of?) he gave during an interview is given in Table 14.

At the same occasion Anirah presented a text for continuing a pantun story after a break; see Table 15 . 
$1 \quad$ Nu kurung di tungtung disaur

2 Nu séda di tungtung sabla

3 Nu hadé geusan nunda carita
Our story comes to an end a The magic words (of the ancestors) will stop

The good things have been done, the story has been finished

a This is a rather free translation. Kurung is cage and nu kurung literally 'what is in the cage'; di tungtung disaur: 'the end of what will be said.'

TABLE 15 Words for continuing a pantun story after a temporary end

$\begin{array}{lll}1 & \text { Mula awaking } & \text { I will start } \\ 2 & \text { Maké pasaduan a pantun } & \text { To ask forgiveness for the pantun story } \\ 3 & \text { Rék nyaritakeun } & \text { I want to tell } \\ 4 & \text { Popotongan nu baréto } & \text { The part that was not told yesterday } \\ 5 & \text { Sisikian }{ }^{\text {b }} \text { kalamari } & \text { Several seeds of yesterday } \\ 6 & \text { Ayeuna rék dicaritakeun deui } & \text { I would like to start telling }\end{array}$

a According to Pleyte (1912: 294, footnote 6) the transcribed pantun singer elsewhere used rajah instead of pasaduan.

b I am not sure about this word; in my field notes I wrote sisi kitan, instead of sisikian.

Music Transcription Tr 5 represents the first 19 lines of Sajin's recited rajah as given in Table 10 above and recorded in $\left.<A V_{12}\right\rangle$. The original was about a semitone lower than in this transcription and the kacapi accompaniment is not included. From the transcription it is clear that the range of the voice is a little smaller than one octave: from a lowest note $\mathrm{D}$ to the highest note $\mathrm{B}$. In the transcription the major notes are notated as D, E, F\#, A and B (d); see also Music Transcription $\operatorname{Tr} 1$ in Section 5.1. The intervals between the notes are taken to be 'more or less the same': the saléndro tone system. It may also be seen from the transcription that the number of notes per time unit varies considerably. Hence the two singing styles cirambay (for instance in line 1) and pada ramé (for instance in line 6) are both used in the beginning of the rajah. $^{33}$

33 Compare Pleyte (1907: 26-27) who reported that the head (kokolot) of Cibéo, who could also play the kacapi, had said that there was only one melody for performing a pantun story and it was called jurit (fight). I have not heard this word myself from Baduy. 


\section{Rajah pantun}

Introduction to Lutung Kasarung pantun story recited by Sajin from Cisadané, 1977

Rubato ca..$=84$
Recorded on LK,1 00-1:45, Jakarta, 8-9 January 1977 original is one semitone lower
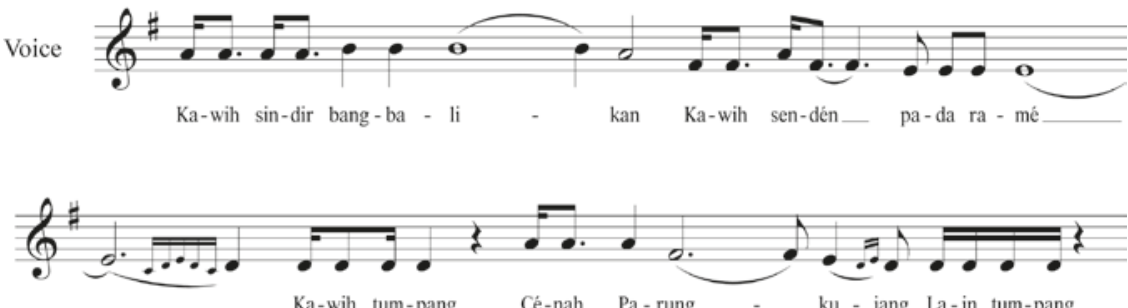

Ka-wih tum-pang Cé-nah $\mathrm{Pa}$-rung _ $\quad \mathrm{ku}$ - jang $\mathrm{La}$-in tum-pang

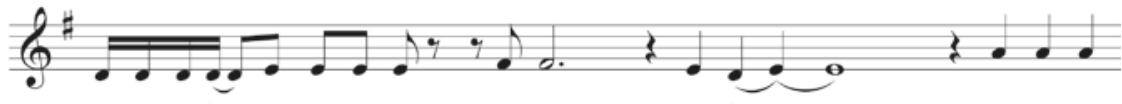

Pa-rung-ku-jang Tung-gal tum-pang

Pa-rung

ku - jang
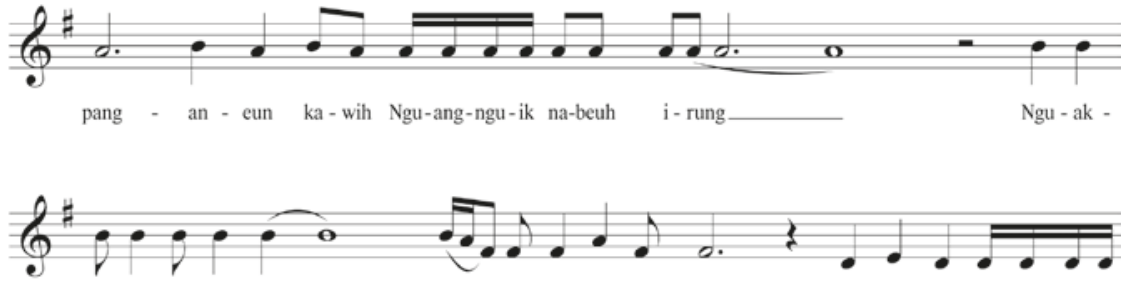

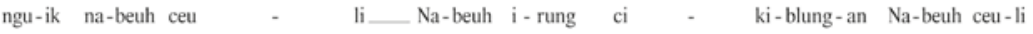

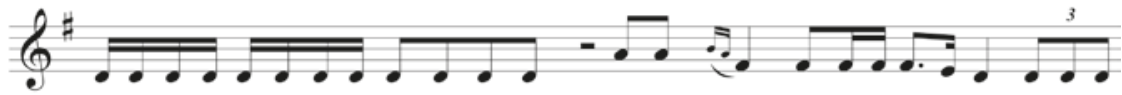

ka-ka-wih-an Ka-wih teu pu-guh mu-bu-san Ka-wih ta - tam-bal-an ti - i-seun Pa-ran-ti

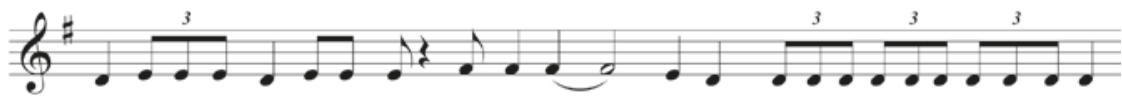

nga-suh nu pun-dung $\mathrm{Pa}-\mathrm{ran}$ - ti ngam-bat nu__ leumpang Pa-ran-ti nga-le-ga nu nga-ling-sig

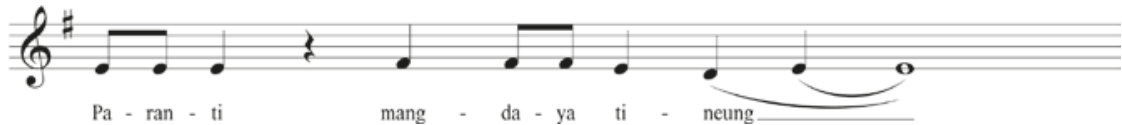

MUSIC TRANSCRIPTION TR 5 Beginning of rajah in pantun recitation by Sajin, 8-9 January 1977. Listen to $<\mathrm{AV} 12>$; see translation of text in Table 13 above 


\section{Goong sosorogan}

From pantun story Lutung Kasarung, recited by Sajin from Cisadané, 1977

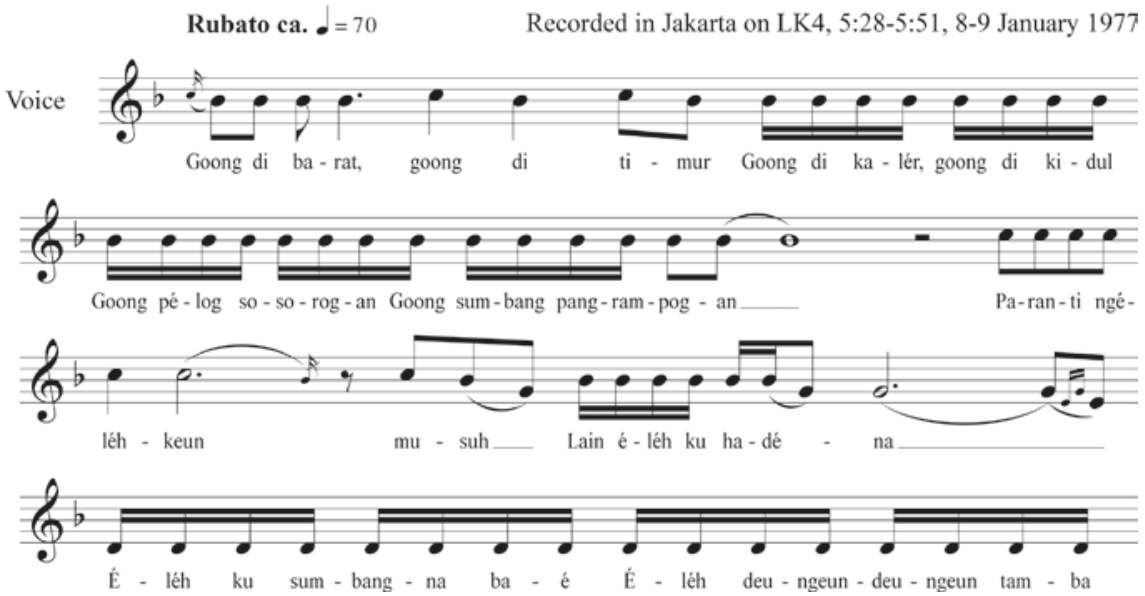

MUSIC TRANSCRIPTION TR 6 Sajin's pantun recitation of text about the false gong, Jakarta, January 1977

Music Transcription Tr 6 represents Sajin's recitation of the text given in Table 13 (metaphor of the false gong) and recorded on $<\mathrm{AV}_{17}>$. This text was sung after about $1 \frac{1}{2}-2$ hours of singing, and it seems that Sajin was singing on a slightly higher pitch than the one used in the rajah at the beginning. Moreover, Sajin was still using a saléndro tone system, but the intervals between the notes D, E, G, B-flat, C (d) were slightly different from those in the rajah. The wholenote and one-and-a half note intervals in one octave are now: $1-1 \frac{1 / 2}{2} 1^{1 / 2}-1-1$, whereas in the rajah singing it was closer to $1-1-1 \frac{1}{2}-1-1 \frac{1}{2}$. This is confirmed by the used PRAAT analysis. It seems to support what was said in Section 5.1: conceptually the saléndro tone system is equidistant, but in practice Baduy musicians deviate from this model and have little problems to change between different versions of the saléndro system. This is similar to what Simon Cook and I have said about Cianjuran music: 'in a cognitive sense the Sundanese saléndro tone system is equidistant' (Cook 1993; Van Zanten 2014: 216-217).

During the rajah Sajin strummed the kacapi about fifteen times. In the goong sosorogan section represented in Table 13 and transcription $\operatorname{Tr} 6$, he did not play the zither. Immediately after finishing the recitation of the $\mathrm{Lu}$ tung Kasarung story I recorded the tuning of the Sajin's zither that was later analysed. These results are also summarized in Table 16 below. If the instrument would have been tuned according to a perfect division of the octave (interval of 12 semitones or 1200 cent) in 5 equal parts, the cent difference 


\begin{tabular}{|c|c|c|c|c|c|c|c|c|c|c|c|c|c|c|c|c|c|c|c|}
\hline String\# & 1 & & 2 & & 3 & & 4 & & 5 & & 6 & & 7 & 8 & 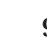 & & 10 & & 11 \\
\hline Hertz & 479 & & 433 & & 364 & & 323 & & 280 & & 240 & & 221 & 178 & & 53 & 142 & & 126 \\
\hline$\approx$ Western & $a^{1 \#}$ & & $a^{1}$ & & $\mathrm{f}^{1} \#$ & & $e^{1}$ & & $c^{1 \#}$ & & b & & a & $\mathrm{f}$ & ( & & $c \#$ & & B \\
\hline $\begin{array}{l}\text { semitone and } \\
\text { cent deviation }\end{array}$ & +48 & & -28 & & -28 & & -37 & & +19 & & -50 & & +8 & +29 & & 21 & +37 & & +42 \\
\hline $\begin{array}{l}\text { Cent difference } \\
\text { between } \\
\text { strings }\end{array}$ & & 175 & & 301 & & 207 & & 247 & & 267 & & 143 & 375 & & 152 & 239 & & 207 & \\
\hline
\end{tabular}

between each pair of consecutive strings should have been 2.4 semitone or 240 cent. However, Sajin's zither had intervals that are much smaller $(175,143$, 152 cent) and much larger (301, 375 cent). It seems that for individual players there is a great tolerance for actual size of musical intervals, within the general saléndro model.

In 2003 it was less clear that Sawari was singing in a saléndro tone system, at least it was less clear than in Sajin's performance in 1977. However, Sawari used more embellishments (grace notes) in his singing than Sajin.

In this chapter I have tried to summarize what we know about Baduy pantun, which is still fairly limited, because we have not yet collected and analysed sufficient field-data. It is also essential that more audio and audio-visual recordings are made available. These would be useful both to check earlier conclusions and as a basis for more musical analysis. The data I have presented here are based on my two recordings of Baduy pantun by Sajin in 1977 and Sawari in 2003 and short fragments sung by Anirah in 2016.

What has been said of the Baduy pantun is also more or less true of the pantun in the wider area of west Java. So far the full texts of pantun stories collected by Pleyte and Rosidi remain the major sources publicly available. The large collection of thirty audio-recorded pantun of Ajip Rosidi's project in the 1970s should be traced and, if still existing, soon become available in digitalized form; before the tapes will have decayed. Fortunately the unique recording of the beginning of a pantun made by Snouck Hurgronje in 1905 has recently been digitalized and is now available for analysis. See further Van Zanten (2016a: Appendix 1) for a list of about forty audio-visual recordings of Sundanese pantun stories, including five recordings of Baduy stories. 
The next chapter will look at the music for entertainment, which resembles what was called the pada ramé singing in the pantun recitation: animated singing that is not immediately connected to the ritual context, but concerned with worldly matters, mainly human love, and that may distract from the major Baduy task of practising asceticism (tapa). 